По суті, діти були віддані на «виховання» чужим людям. Цей випадок - приклад того, як не потрібно виховувати дітей, адже і сьогодні є чимало батьків, які свідомо усуваються від цього важливого обов'язку заради власного комфорту та зручностей. Вони «виключають» своїх дітей зі свого «дорослого» суспільства, ненав' язливо «відтіснивши» у суспільство «дитяче». Чому так відбувається? Чому в деяких батьків такий низький рівень відповідальності за найдорожче, що вони мають у цьому житті?

А. С. Макаренко у своїх працях частково дає відповідь на ці та багато інших запитань, що стосуються виховання дітей, зокрема він пише, що відмовки про нестачу часу вигадали батьки-невдахи, і що для прояву батьківської уваги потрібно «уміло використовувати свій час» $[4$, с. 5]. Педагог акцентує увагу на тому, що батьківський обов'язок перед дитиною - це «особлива форма обов'язку перед суспільством», суспільству потрібні гарно виховані громадяни. А щодо батьків, в яких не вистачає часу, педагог зауважує: «Виховання вимагає набагато більше душі, неослабної уваги, все більш зростаючого почуття відповідальності, а не часу. I чим старша дитина, тим менше вона потребує часу, але тим більша за неї відповідальність...» [5, с. 1]. Варто пам'ятати також слова Антона Семеновича про те, що батьківська любов вимірюється не кількістю подарунків, а відповідальністю перед дитиною та суспільством. А щодо виправдань батьків про нестачу часу для виховання, то думка педагога однозначна: «... усі ці виправдання нічого не варті - не часу мало в таких батьків, у них відсутнє почуття відповідальності перед власною дитиною та перед суспільством» $[5$, с. 1$]$.

Насамкінець хочемо зауважити, що головний принцип педагогічної системи видатного педагога «живіть із дітьми одним життям, одним колективом...» [2, с. 1], тобто будьте 3 ними єдиним цілим, впустіть їх у своє «доросле суспільство» - i досі залишається надзвичайно актуальним.

Висновки. Отже, поняття «соціальна інклюзія» слід розуміти не лише як «включення» дітей 3 особливими потребами у загальноосвітній процес, а також і як «включення» всіх без винятку дітей до «суспільства дорослих». Цей різновид соціальної інклюзії $\epsilon$ на сучасному етапі важливим аспектом розвитку соціуму, адже діти у будь-якому віці надзвичайно потребують уваги дорослих, насамперед батьків, які не повинні перекладати свої обов'язки на педагогів та оточення, а усвідомити, що саме від них залежить, якою їхня дитина увійде у доросле життя.

\section{СПИСОК ВИКОРИСТАНОЇ ЛІТЕРАТУРИ}

1. Закон України «Про освіту» від 05.09.2017 № 2145-VII [Електронний ресурс]. URL: https:// zakon.rada.gov.ua/laws/show/2145-19 (дата звернення: 20.05.2019).

2. Косинцева Д. Шесть принципов, которым советский педагог Макаренко может научить современную маму [Электронный ресурс] / Д. Косинцева // Матроні.RU - консервативный женский журнал. - 2018. URL: http://www.matrony.ru/6-printsipov-kotoryimsovetskiy-pedagog-makarenko-mozhet-nauchit-sovre mennuyu-mamu/ (дата звернення: 15.05.2019).

3. Майорова-Щеглова С. Н. Трансформации детства в начале XXI века: к уточнению концепции социального конструирования детства [Электронный ресурс] / С. Н. Майорова-Щеглова // Сайт «CYBERLENINKA».-2014.URL:https://cyberleninka. $\mathrm{ru} /$ article/n/transformatsii-detstva-v-nachale-xxi-v-kutochneniyu-kontseptsii-sotsialnogo-konstruirovaniyadetstva-1 (дата звернення: 16.05.2019).

4. Макаренко А. С. Лекции о воспитании детей [Электронный ресурс] / A. C. Макаренко. URL: www.makarenko.edu.ru/files/lekcii_o_vospitanii.doc (дата звернення: 20.05.2019).

5. Макаренко А. С. Советы родителям [Электронный ресурс] / А. С. Макаренко // Избранные произведения : в 3 т. - К. : Радянська школа, 1985. - Т. 3. - 592 с. URL: http://az.lib.ru/m/makarenko_a_s/text_1937_sovety_ roditelyam.shtml (дата звернення: $\overline{20} .05 .2 \overline{0} 19)$.

Дата надходження до редакиії: 18.06.2019 р.
УДК 37.091.4:37.091.214.18

DOI: 10.37026/2520-6427-2019-99-3-12-15

\author{
Алла КОРОЛЮК, \\ старша викладачка кафедри \\ природничо-математичної освіти \\ Рівненського ОІППО
}

\title{
ПРО МІЖПРЕДМЕТНІ ЗВ'ЯЗКИ У ТВОРЧОМУ ДОРОБКУ В. О. СУХОМЛИНСЬКОГО
}

У статті основна увага приділяється питанню реалізації міжпредметних зв'язків математики з іншими шкільними дисциплінами. Доведено необхідність комплексного розв'язання проблеми. Проаналізовано педагогічні ідеї В. О. Сухомлинського щчодо міжпредметних зв'язків та їх ролі у формуванні изілісної картини світу.

Ключові слова: інтеграція навчання, математика, міжпредметні зв'язки, педагогічна спадщчина В. О. Сухомлинського. 
В статье основное внимание уделяется вопросу реализации межпредметных связей математики с другими школьными дисциплинами. Доказана необходимость комплексного решения проблемы. Проанализированы педагогические идеи В. А. Сухомлинского по межпредметных связей и их роли в формировании иелостной картины мира.

Ключевые слова: интеграция обучения, математика, межпредметные связи, педагогическое наследие В. А. Сухомлинского.

The article draws attention to the issue of implementation of the intersubject links of mathematics with other school subjects. It is underlined the ambiguous interpretation of the concept of «intersubject links» in the works of domestic and foreign scientists. It is emphasized that the purposeful implementation of the intersubject links forms the students' ability to perceive the whole world in a holistic way, the ability to independently establish significant cause-and-effect relations between objects and phenomena.

Based on the analysis of the works of V. O. Sukhomlynskyi, the article has proven that the combination of theoretical generalizations of one discipline with the generalizations of another, or several others, as well as their application in practice, provides the transformation of knowledge and enhances their connection with the life.

The pedagogical ideas of $V$. O. Sukhomlynskyi regarding intersubject links and their role in forming a holistic picture of the world have been analyzed. It is clarified the importance of mathematics in the intersubject links and in mental development of the students. It is drawn attention to the fact that the formation of students' holistic knowledge is impossible without the connection of the study with the life, conscious and quality acquisition of knowledge by the students. In order to help the students to form the holistic knowledge, it is necessary to teach them to observe the surrounding life, to make necessary researches, to explain the received results, to involve them in independent performance of practical tasks.

The proposed article is an attempt to analyze the heritage of the prominent domestic teacher and to find recommendations that can be used in the implementation of the intersubject links and in the process of forming the scientific picture of the world by the modern students. The systematic use of different types of the intersubject links is an important resource which should significantly update the current techniques in order to form the key and subject competences.

Key words: integration of study; mathematics; intersubject links; pedagogical heritage of V. O. Sukhomlynskyi.

Постановка проблеми. Дієвою умовою підвищення ефективності освітнього процесу та вдосконалення якості знань учнів є встановлення та реалізація міжпредметних зв'язків у процесі вивчення предметів природничого циклу. Сучасний рівень розвитку науки яскраво виражає інтеграцію суспільних, природничих і технічних знань. Міжпредметні зв'язки в шкільному навчанні $\epsilon$ проявом інтеграційних процесів, що відбуваються сьогодні в житті суспільства загалом та в науці зокрема.

Аналіз наукових досліджень і публікацій. Теоретичну основу дослідження складають праці вітчизняних і зарубіжних науковців, зокрема П. Р. Атутова, С. В. Бабаджанян, I. І. Бавріна, Г. І. Батуріної, В. Г. Бевз, Г. В. Бібік, О. І. Бугайова, М. Я. Віленкіна, С. М. Дворяткіної, О. І. Сфремової, І. Д. Звєрєва,
Д. М. Кирюшкіна, С. В. Коршака, В. М. Максимової, В. М. Монахова, М. М. Скаткіна, В. М. Федорової та ін. Аналіз наукових праць означених вище дослідників дає змогу стверджувати про неоднозначне трактування поняття «міжпредметні зв'язки», зокрема, розглядаючи їх із позиції цілісності процесу навчання, їх класифікують на:

- змістово-інформаційні міжпредметні зв'язки встановлюються під час формування змісту елементів знань (фактів, уявлень, понять, теорій) у процесі осмислення їх ознак і властивостей;

- операційно-діяльнісні міжпредметні зв'язки пов'язані зі способами пізнавальної діяльності (використання загальнонавчальних, творчих, мовних, оціночних умінь);

- організаиійно-методичні міжпредметні зв'язки функціонують у самому процесі навчання та здійснюються за допомогою різних методів і форм, вони збагачують загальні методи, прийоми і форми навчання професійного іншомовного спілкування, а також забезпечують ефективні шляхи засвоєння студентами загальнопредметних знань і вмінь [2].

Аналіз напрацьованого досвіду з даної теми дає підстави стверджувати, що питання інтеграції предметів природничо-математичного циклу в умовах сучасної української школи вимагає розв'язання цілого ряду проблем різного рівня складності. Зокрема, недостатньо методичних рекомендацій для координації діяльності вчителів-предметників, які не можуть повною мірою здійснювати міжпредметні зв'язки через необізнаність у змісті програм із суміжних дисциплін. Крім того, для використання міжпредметних зв'язків потрібна узгодженість змісту освіти з різних навчальних предметів, побудова та відповідний відбір матеріалу. Зважаючи на це, виникла необхідність звернутися до педагогічної спадщини видатного педагога В. О. Сухомлинського, аби обгрунтувати проблеми реалізації міжпредметних зв'язків із перспективою на міжпредметну інтеграцію.

Мета статті - аналізуючи спадщину В. О. Сухомлинського, віднайти у ній рекомендації щодо використання міжпредметних зв'язків із метою реалізації компетентнісного підходу на уроках математики.

Виклад основного матеріалу. Термін «міжпредметні зв'язки», за визначенням Українського педагогічного словника, - це «взаємне узгодження навчальних програм, зумовлене системою наук і дидактичною метою» [3, с. 210]. Реалізація міжпредметних зв'язків є одним із важливих резервів удосконалення освітнього процесу в умовах профільної диференціації освіти. Використання на уроках різних типів міжпредметних завдань сприяє ефективному формуванню в учнів ключових компетентностей, а отже, міжпредметні зв'язки є важливим ресурсом упровадження компетентнісного підходу [5, с. 50].

В. О. Сухомлинський одним із перших усвідомив значимість взаємозв'язків як важливої умови формування цілісних знань, які допомагають учневі глибоко усвідомити ключові ідеї шкільних предметів. Педагог аргументовано довів необхідність забезпечення навчальної інтеграції й описав власний практичний досвід їх використання. Він, зокрема, наголошував, що «знання перетворюються у дійовий фактор тоді, коли особистий погляд на явища навколишнього світу охоплює всі сфери духовного життя вихованця його мислення, почуття, волю, діяльність» $[9$, с. 92]. 
Підкреслюючи важливість міжпредметних зв'язків, педагог охарактеризував внесок кожного предмета у всебічне бачення учнем навколишнього світу. Так, математика, на його думку, - це не лише основа математичного мислення, а й «світоглядний предмет, який проникає в усі науки, що вивчають і природу, і суспільне життя. Математичне мислення - це не тільки розуміння кількісних, просторових, функціональних залежностей між числами, величинами, геометричними фігурами, а ще й своєрідний підхід до дійсності, метод дослідження фактів і явищ природи, суспільного життя, праці, економіки, засіб аналізу причинно-наслідкових зв'язків між явищами». Математика як навчальний предмет «накладає відбиток на всю розумову працю в процесі навчання, на характер спостережень за явищами природи при вивченні біології, фізики, хімії, астрономії. Ідеї функціональної залежності та змінної величини, які відіграють значну роль при вивченні математики, розвивають діалектичне мислення, полегшуючи розуміння причинно-наслідкових зв'язків при вивченні інших предметів...» [8, с. 235-236].

«...Математичні методи доведення учні використовують при аналізі явищ природи, зокрема під час спостережень, пов'язаних із вивченням механіки. Використання прийомів математичного мислення при пізнанні світу й у праці - одна 3 головних ліній зв'язку теорії з практикою в процесі вивчення математики. Використовуються методи математичного доведення і при вивченні хімії. Великого значення ми надаємо використанню математичних методів при правильному виборі шляхів досягнення кінцевої мети праці, аби порівняти достоїнства та недоліки окремих шляхів. Неабияке значення математики й у вихованні працелюбності, акуратності, критичності» [там само].

В. О. Сухомлинський наголошував на важливості не лише змісту міжпредметних зв'язків, а також визначив їх як метод навчання, як характер навчальної діяльності вчителя: «...Про міжпредметні зв'язки говорять дуже багато. Кожному вчителю зрозуміло, що потрібно шукати у своєму предметі точки дотику з матеріалом інших предметів. Але міжпредметні зв'язки полягають не лише в цьому. Найбільш глибокі зв'язки лежать не стільки в змісті фактичного матеріалу, скільки в характері розумової праці. Побудована на науковій основі розумова праця учнів призводить до того, що математика допомагає дитині засвоювати історію, а історія сприяє розвитку математичних здібностей» [7, с. 487-489].

«Без активної розумової праці неможливі ні інтеpec, ні увага школярів», «знання істини народжуються у свідомості учня з пізнання точок зіткнення між фактами і явищами, ниток, якими ці факти і явища пов'язуються», - наголошував Василь Олександрович [7, с. 479].

Усі представлені вище положення В. О. Сухомлинського підтверджені фактами не лише 3 його власного вчительського досвіду, а й із досвіду роботи його колег - учителів Павлиської школи. При цьому педагог приділяв особливу увагу підготовці вчителя до уроку, зокрема до відбору матеріалу, що викладатиметься учням на уроці. «Готуючись до уроку, - писав Сухомлинський, - слід продумати, осмислити якраз ті точки зіткнення, ті нитки, де завдяки «зчіпленню» думок розкривається щось нове, несподіване 3 погляду пізнання істин і закономірностей навколишнього світу» [там само]. Наприклад, він рекомендує пропонувати учням такі завдання, виконання яких потребує знань двох-трьох узагальнень iз різних предметів. «Під час виконання таких завдань відбувається надзвичайно потрібний для розумового розвитку процес трансформації знань - узагальнюючі істини переосмислюються в їх взаємозв'язках і взаємозалежностах. Учень сприймає факти, предмети, явища з нового, невідомого раніше для нього боку» [7, с. 467]. Під час виконання саме таких завдань відбувається поєднання знань, «одне теоретичне узагальнення стикається, пов’язується, «зчіплюється» 3 іншим, відбувається немовби стрибок у трансформації знань: обидві істини глибше осмислюються, учень бачить у теоретичних узагальненнях те, чого він раніше не бачив, ясність одного немовби робить яснішим інше» [там само].

В. О. Сухомлинський наголошував, що всі дисципліни, які вивчаються в школі, неабияк потрібні, адже кожен школяр повинен бути певною мірою і математиком, і фізиком, і хіміком, і літератором, й істориком. Шкільні знання необхідні для формування в дитини об'єктивного сприйняття оточуючої дійсності та внутрішнього світу, на основі якого дитина сприйматиме зовнішній світ. Таким чином, педагог не обмежується лише вказівкою на розвиток діалектичного мислення в процесі реалізації взаємозв'язків у навчанні, а спрямовує вчителів на більш глибокий підхід до вирішення цієї важливої дидактичної проблеми.

У праці «Сто порад учителеві» Василь Олександрович наголошує на важливості грунтовного опрацювання матеріалу при першому вивченні, уважному відношенні вчителів до процесу усвідомлення фактів, законів, які у подальшому можуть стати основою для вивчення тем і розділів 3 іншого предмета. «Багаторічний досвід переконав: джерело нетривкості знань у слабо встигаючих учнів у тому, що вони не бачать, не розуміють зв'язку фактів, явищ, істин, закономірностей, - «точок», де народжуються причинно-наслідкові, функціональні, часові та інші зв'язки. Ось на ці «точки» й потрібно звертати увагу», - писав учений. При цьому він неодноразово наголошував, що «знати - це значить уміти застосовувати знання», які «... стають чинником духовного життя, захоплюють думку, пробуджують інтерес» [7, с. 452].

У своїх працях він давав поради і навчав інших вчителів: «... Треба прагнути до активності думки учня, до того, щоб знання розвивалися завдяки їх застосуванню. Учити так, щоб знання добувалися за допомогою наявних уже знань» [7, с. 454]; «...повсякчас підтримувати, поглиблювати бажання учня бути відкривачем, реалізувати це його бажання спеціальними методами роботи» [7, с. 480]. Саме цих порад дотримувалися вчителі Павлиської школи, застосовували дослідницький підхід на уроках природничо-математичного циклу та в позаурочний час. Завдяки спостереженням, дослідам, аналізу явищ навколишнього світу, власній діяльності, проведенню практичних робіт учні ставали активними здобувачами знань, дослідниками нових для них явищ і речей.

Отже, Сухомлинський намагався відкривати як для своїх колег-педагогів, так і вихованців світ у всій його повноті, зокрема знайомити учнів із новими явищами, показуючи їх взаємозв'язок; він прагнув сформувати у своїх вихованців цілісні і повноцінні знання основ наук, які були б тісно пов'язані зі знаннями про оточуючий світ і саме життя. Педагог вважав, що для того, щоб це реалізувати, не потрібно створювати штучних бар'єрів, а поєднувати навчання з мисленням, творчістю та спостереженням за природою рідного краю [4].

Висновки. Отже, міжпредметні зв'язки - це не лише «мости» між навчальними дисциплінами, а насамперед засіб побудови цілісної системи навчання на основі спільності змісту знань і методів наукового пізнання. 
Правильно застосувавши їх, процес навчання стає цікавим і неповторним дійством. Про це свого часу наголошував і В. О. Сухомлинський, настанови якого і сьогодні, на початку XX століття, не втрачають своєї актуальності.

Запропоновані нами у статті положення видатного педагога про значимість міжпредметних зв'язків важливі насамперед тому, що орієнтують учителів на їх організацію, поетапне формування міжпредметних понять, використання проблемних запитань і задач, а як наслідок - сприяють розвитку в здобувачів освіти таких важливих якостей, як спостережливість, допитливість, уміння самостійно аналізувати явища навколишнього світу.

\section{СПИСОК ВИКОРИСТАНОЇ ЛІТЕРАТУРИ}

1. Барановська О. Модернізація змісту профільного навчання в світлі міжпредметної інтеграції / О. Барановська // Директор школи, ліцею, гімназії. 2015. - № 5. - С. 94-100.

2. Бевз В. Г. Міжпредметні зв'язки як необхідний елемент предметної системи навчання / В. Г. Бевз // Математика в школі. - 2003. - № 6. - С. 11-15.

3. Гончаренко С. У. Український педагогічний словник / С. У. Гончаренко. - Київ : Либідь, 1997. - 376 с.
4. Остраус М. Ю. Реалізація міжпредметних зв'язків у педагогічній спадщині Василя Олександровича Сухомлинського [Електронний ресурс]. URL: http://intkonf.org/ostraus-yu-m-realizatsiya-mizh predmetnih-zvyazkiv-v-pedagogichniy-spadschinivasilya-oleksandrovicha-suhomlinskogo/ (дата звернення: 20.06.2019).

5. Савченко О. Я. Міжпредметні зв'язки як ресурс реалізації компетентнісного підходу на уроках літературного читання / О. Я. Савченко // Український педагогічний журнал. - 2017. - № 2. - С. 48-57.

6. Сухомлинський В. О. Розмова з молодим директором школи / В. О. Сухомлинський // Вибрані твори : в 5 т. - К. : Рад. школа, 1976. - Т. 1. - С. 393-629.

7. Сухомлинський В. О. Сто порад учителеві / В. О. Сухомлинський // Вибрані твори : в 5 т. - К. : Рад. школа, 1979. - Т. 2. - С. 419-655.

8. Сухомлинський В. О. Павлиська середня школа / В. О. Сухомлинський // Вибрані твори : в 5 т. К. : Рад. школа, 1977. - Т. 4. - С. 2-640.

9. Сухомлинський В. О. Проблеми виховання всебічно розвиненої особистості / В. О. Сухомлинський // Вибрані твори : в 5 т. - К. : Рад. школа, 1976. T. 1. - C. 5-208.

Дата надходження до редакиї: 20.08.2019 р.
УДК 37.091.4(092)

DOI: $10.37026 / 2520-6427-2019-99-3-15-20$

\section{Олександр МІХНО,}

кандидат педагогічних наук, стариий науковий співробітник відділу наукової реферативної та аналітичної інформації у сфері освіти Державної науково-педагогічної бібліотеки Украӥни імені В. О. Сухомлинського, м. Київ

\section{АКОРДИ ТА АКЦЕНТИ БІОГРАФІЇ ВАСИЛЯ СУХОМЛИНСЬКОГО (методичні поради для вчителя за книгою Бориса Тартаковського «Повість про вчителя Сухомлинського»)}

\begin{abstract}
У статті на основі аналізу змісту та історіі написання твору Б. Тартаковського «Повість про вчителя Сухомлинського» подано методичні рекомендації та поради для педагогів з метою вивчення біографії Василя Сухомлинського. Обгрунтовано доиільність використання в ході вивчення біографіi видатного педагога акордної системи навчання, щзо широко застосовувалася у 20-х роках XX століття. У вигляді таблииі представлено основні акорди та акиенти біографії Василя Сухомлинського.

Ключові слова: Василь Сухомлинський, біографія, акордна система навчання, методичні поради.
\end{abstract}

В статье на основе анализа содержания и истории написания произведения Б. Тартаковского «Повесть об учителе Сухомлинском» представлены методические рекомендации и советы для педагогов с иелью изучения биографии Василия Сухомлинского. Обоснована ичелесообразность использования в ходе изучения биографии выдаюшегося педагога аккордной системы обучения, которая широко применялась в 20-х годах XX века. $B$ виде таблииь представлены основные аккорды и акиенты биографии Василия Сухомлинского.

Ключевые слова: Василий Сухомлинский, биография, аккордная система обучения, методические советь. 